\title{
目
}

Arch. Min. Sci. 62 (2017), 1, 73-82

Electronic version (in color) of this paper is available: http://mining.archives.pl

DOI 10.1515/amsc-2017-0006

\author{
ŁUKASZ MACHNIAK*, WIESŁAW KOZIOŁ**
}

\section{METHOD OF ASSESSMENT OF HARD ROCK WORKABILITY USING BUCKET WHEEL EXCAVATORS}

\section{METODA OCENY URABIALNOŚCI SKAL ZWIĘZEYCH KOPARKAMI WIELONACZYNIOWYMI}

\begin{abstract}
A new hypothesis concerning a process of the mining solid rocks using bucket wheel excavators (BWE). Destroying of the rock mass structure is a result of breaking and not, as so far accepted, of cutting. This approach excludes, for the description of solid rock workability using bucket wheel excavators, used classifications based on individual linear or surface resistances of cutting. The possibility of a replacement mechanism for determining of the workability by bucket wheel excavators using rippers was assumed. On this basis, an innovative method for assessing the workability of solid rocks was developed, which is a combination of an derived empirical energy relationship LSE of breaking by tractor rippers from a compressive strength, a seismic wave velocity, a density of solid rock, and the modified classification of workability by bucket wheel excavators according to Bulukbasi (1991). The proposed method allows for multi-parameter assessment of the workability class based on the parameters that are independent variables in the specified dependencies.
\end{abstract}

Keywords: opencast mining, bucket wheel excavators, workability of solid rocks, hypothesis of the mining using bucket wheel excavators

Dobór efektywnego rozwiązania technicznego w procesie urabiania skał zwięzłych, a zwłaszcza określenie możliwości wykorzystania podstawowych koparek wielonaczyniowych, jest jednym z ważniejszych problemów decyzyjnych na etapie projektowania, jak również w fazie odkrywkowej eksploatacji złóż węgla brunatnego. Dostosowanie maszyn tych do pracy w skałach zwięzłych jest mocno ograniczone, ale możliwe szczególnie w skałach (głównie osadowych) charakteryzujących się niższymi parametrami wytrzymałości, jak również spękanych czy poddanych procesowi erozji. Dotychczas stosowane metody oceny urabialności skał koparkami wielonaczyniowymi, oparte na jednostkowych oporach urabiania, należy ograniczyć głównie do eksploatacji skał okruchowych oraz spoistych. Wynika to z faktu, iż charakter procesu urabiania wielonaczyniowymi koparkami kołowymi, ze wzrostem zwięzłości urabianych ośrodków, odbiega w coraz większym stopniu od modelu procesu skrawania i do ilościowej oceny tego zjawiska nie można stosować miar opartych na dominacji tego procesu (Babiarz i in. 2007; Kołkiewicz, 2006; Machniak, 2013).

* AGH UNIVERSITY OF SCIENCE AND TECHNOLOGY, FACULTY OF MINING AND GEOENGINEERING, AL. A. MICKIEWICZA 30, 30-059 KRAKOW, POLAND

** INSTITUTE OF MECHANIZED CONSTRUCTION AND ROCK MINING, DIVISION IN KATOWICE, 40-157 KATOWICE, POLAND 


\begin{abstract}
W artykule przedstawiono nową hipotezę dotycząca procesu urabiania skał zwięzłych koparkami wielonaczyniowymi. Gdyż niszczenie struktury zwięzłego masywu skalnego następuje w wyniku zrywania, a nie jak do tej pory przyjmowano skrawania. Podejście takie wyklucza, do opisu urabialności skał zwięzłych koparkami wielonaczyniowymi (również jednonaczyniowymi), stosowane klasyfikacje oparte na jednostkowych liniowych bądź powierzchniowych oporach urabiania (Rys. 1). Postawienie nowej hipotezy, w zakresie urabiania skał zwięzłych, uzasadnia porównywanie realizacji procesu urabiania koparkami wielonaczyniowymi z innymi maszynami o takim samych charakterze pracy, np. zrywarkami. Zostaje zatem wprowadzona możliwość zastępczego mechanizmu określania urabialności z wykorzystaniem zrywarek. Parametrem konsolidującym prace obu maszyn jest energia urabiania LSE. Na tej podstawie opracowano metodę oceny urabialności skał zwięzłych koparkami wielonaczyniowymi, będącą połączeniem wyprowadzonej empirycznej zależności energii urabiania LSE zrywarkami ciągnikowymi od wytrzymałości na ściskanie, prędkości fali sejsmicznej, gęstości objętościowej masywu skalnego, i zmodyfikowanej klasyfikacji urabialności koparkami wielonaczyniowymi wg Bulukbasi (1991). Proponowana metoda pozwala na wieloparametrową ocenę klasy urabialności w oparciu o parametry będące zmiennymi niezależnymi w podanej zależności lub bezpośrednio w oparciu o propozycję nowej klasyfikacji urabialności przedstawionej w Tabeli 2.
\end{abstract}

Słowa kluczowe: górnictwo odkrywkowe, koparki wielonaczyniowe, mechaniczna urabialność skał, urabianie skał zwięzłych koparkami wielonaczyniowymi

\title{
1. Introduction
}

In brown coal open pits, wheel, or seldom, chain bucket excavators are used for mining operations. With such technical solution, the predominant problem with exploitation is related to overburden of hard rock. In most brown coal open pits, the overburden is formed of extremely differentiated physical and mechanical properties, starting with cohesive and clastic rock, which internal structure changes negligibly during mining procedure to cohesive rock that pose problems with effective mining or even preclude mining using mechanical means, such as BWE. Overburden structure is mostly composed of cohesive and clastic rocks whereas hard rock is in minority. Despite relatively small volumes of hard rock in the overburden, significant reduction in performance of excavators can be noticed (Kozioł et al., 1990; Kavouridis et al., 2008; Strunk, 2008; Machniak, 2013), and this leads to reduction of mining throughput of the whole mine. In worst case scenario (e.g. combination of hard rocks, no previous identification of their presence, thin benches between the levels), this can seriously affect the planned mining tasks, both in the overburden and coal.

Selection of effective technical solution in the hard rock mining process, especially determination whether basic BWE can be used, is one of the most important issues at the stage of designing and exploiting brown coal deposits. Adaptation of machines to works in hard rock is very limited but possible in rocks (mostly sedimentary rock) characterized by lower strength parameters as well as cracked or subjected to erosion.

\section{Prior art}

Despite many attempts, theory allowing for unequivocal analytical description of the mining process using bucket wheel excavators and other mining machines and devices, e.g. roadheaders in underground mining or tunnelling, could not have been developed.

Two hypotheses concerning mining process currently apply (Kołkiewicz, 1973, 2006; Kramdibrata, 1998; Szepietowski, 1991). The first of them (adopted mostly in the countries of 
Eastern Europe) assumes that in the mining process, energy is spent mostly on the lump in the glide plane, passing the cutter edge and approximately perpendicularly to the cutter leading edge. Based on this, it is assumed that mining force is directly proportional to the cross-section of the cut lump. Thus, the index $k_{F}$ (unitary, superficial mining resistance), which is the relation of mining force to the lump cross-section is a magnitude characteristic for a given rock and can represent the measure of workability. The second hypothesis (adopted in Germany and countries of Central Europe) assumes that the mining process consists mostly in destructing rock by the cutting edge of cutter. Thus, workability measure can be the index $k_{L}$ (unitary, linear mining resistance) equal to the mining force and active length of bucket edge. Hence, the most popular classification of rocks workability using bucket wheel excavators used in the mining industry are based on unitary linear and superficial mining resistances (Kołkiewicz, 1973; Davies, 1991; Kozioł \& Machniak, 2010; Machniak, 2013). Among these classifications, a few workability classes were distinguished, starting with very easy workable to not mechanically workable. Another common feature is determination of workability class both for clastic rock (e.g. sand and gravel), cohesive (e.g. clay, slit) as well as for hard rock such as marl, limestone, conglomerates or sandstone. Workability classes acc. to Kołkiewicz (1973) and Davies (1991) are limited with very similar unitary values of superficial mining resistances. Moreover, Davies (1991) in his classification used the geophysical measurements, especially acoustic wireline logging, assigning a range of time, for the acoustic wave to pass, to individual classes, as the new parameter of workability assessment. Due to small diameter of bores, drilling geophysics allows for recognizing sediment in a limited near-bore zone, however information gathered this way is the most accurate among all geophysical methods. In case of irregular or scattered network of holes, data correlation can be difficult (Kozioł at al., 2013).

According to Kozioł and Machniak's (2010) as well as Machniak's (2013) classification, technical development is considered, concerning effective mining with bucket wheel excavators. Authors proposed separate mining classes for old and new type excavators as well as change of the limiting value of mining resistance for individual workability classes.

The most accurate and reliable method of measuring unitary resistances are direct measurements using a specified BWE under given operating conditions. This significantly complicates the workability tests. Because of this, easier methods (economical dependencies) were developed, consisting in determining mining resistances based on some physical and mechanical features of mined rocks, such as bulk density, content of clay fraction, cohesion, internal friction angle, strength to uniaxial compression, etc. These dependencies were presented among other things in the paper of Szepietowski (1991) called "Identyfikacja i modelowanie..." [Identification and modelling...] (1995). Comparison of the characteristics of rock massif, especially of cohesive massif, based on correlation dependencies of workability resistance with the results of research on actual objects (direct measurements of workability on excavators) showed that these are indeed different. This results from the fact that actual lithological and structural formation of mined material is far more differentiated. Mineral composition, size distribution, presence of cracks and other surfaces of reduced strength frequently appear to be locally variable, which fact is translated to differentiated mining conditions.

Physical and mechanical parameters of rock massif are also directly used for the workability assessment. Mostly, this parameter is strength to uniaxial compression. Proposal of such classification is given by Shroeder and Trupmer (1993), who determined that the limiting scope of BWE application is the strength of $20 \mathrm{MPa}$. Other example can be the classification based on Protodiakonov cohesion index, employed in Brown Coal Mine "Bełchatów". Because it is 
possible to mine using excavators, hard rock in the overburden is divided to three basic groups (Characteristics..., 2004):

- mechanically workable; $0.1<f<1.5$,

- conditionally workable; $1.5<f<2.0$,

- not workable; $f>2.0$.

The scope of application of BWE, alike in case of Schroeder and Trumper classification (1993), was also limited to $20 \mathrm{MPa}$, however it does not exclude narrowing the scope of excavators application to lesser value of compression strength (15 MPa). In case of conditionally workable rock, the additional parameter is missing, which could be used for unequivocal determination of workability. Until now, mining with excavator is authorized by technical services after performing direct workability tests.

In turn, Abdullatif and Cruden (1983) in their paper, express workability using the RMR index (Bieniawski). Application of bucket wheel excavators according to this classification is possible to RMR index $<30$. This classification, even though it is determined based on a single parameter, can be recognized as multi-parameter. The RMR index (Bieniawski, 1975), determined based on six features of rock massif, very accurately reflects its quality, thus, indirectly, workability.

Different method of workability of rock was presented by Bolukbasi et al. (1991). The classification is based on the results of mining energy LSE $\left(\mathrm{MJ} / \mathrm{m}^{3}\right)$ (Tab. 1).

TABLE 1

Workability classification using BWE based on LSE parameter (Bolukbasi et al., 1991)

\begin{tabular}{|c|c|c|c|}
\hline \multirow{2}{*}{ Workability class } & \multicolumn{3}{|c|}{ Mining energy $\left[\mathrm{MJ} / \mathrm{m}^{3}\right]$} \\
\hline & Minimum & Maximum & Average \\
\hline Easily workable & 0.5 & 1.9 & 1.2 \\
\hline Workable & 1.9 & 3.7 & 2.8 \\
\hline Tough workable & 3.7 & 4.8 & 4.2 \\
\hline Very tough workable & 4.8 & 8.6 & 6.7 \\
\hline Not workable & 8.6 & - & 8.6 \\
\hline
\end{tabular}

It distinguishes five classes of workability from easily workable to not workable. This classification, in its modified form, will be one of the elements of the workability assessment methods proposed in this paper.

\section{Proposed methodology of assessment of hard rock workability using bucket wheel excavators}

The basis for development of new method of bucket wheel excavators workability forecasting is the adoption of the hypothesis within the scope of hard rock workability, which says that destroying the structure of rock massif body occurs as a result of ripping by forced penetration of cutting edges without separating ripped lump. Focused pressure on the rock body applied by cutter edges cause its cracking, most frequently along discontinuities (cracks) and damaging its original structure. The role of bucket cutting edge is limited to forcing the process of filling the bucket with the loosened mining. 
Currently applied hypotheses should mostly be limited to exploitation of clastic and cohesive rock. This results from the fact that mining process character, together with the increase of cohesion of mined material, departs from the cutting process model and from quantitative assessment of this phenomenon and measures based on domination of this process cannot be applied. In cohesive rock, qualitative change of the process of loosening the mining from the body occurs, starting with cutting process to ripping process. Workability in such cases depends not only on the parameter of unitary mining force, which is characteristic for the cutting process, but also on physical and mechanical parameters of the rock massif and bucket wheel design (Machniak, 2013). Procedure in case of workability assessment and selection BWE depending on the rock classification type is presented on the Figure 1.

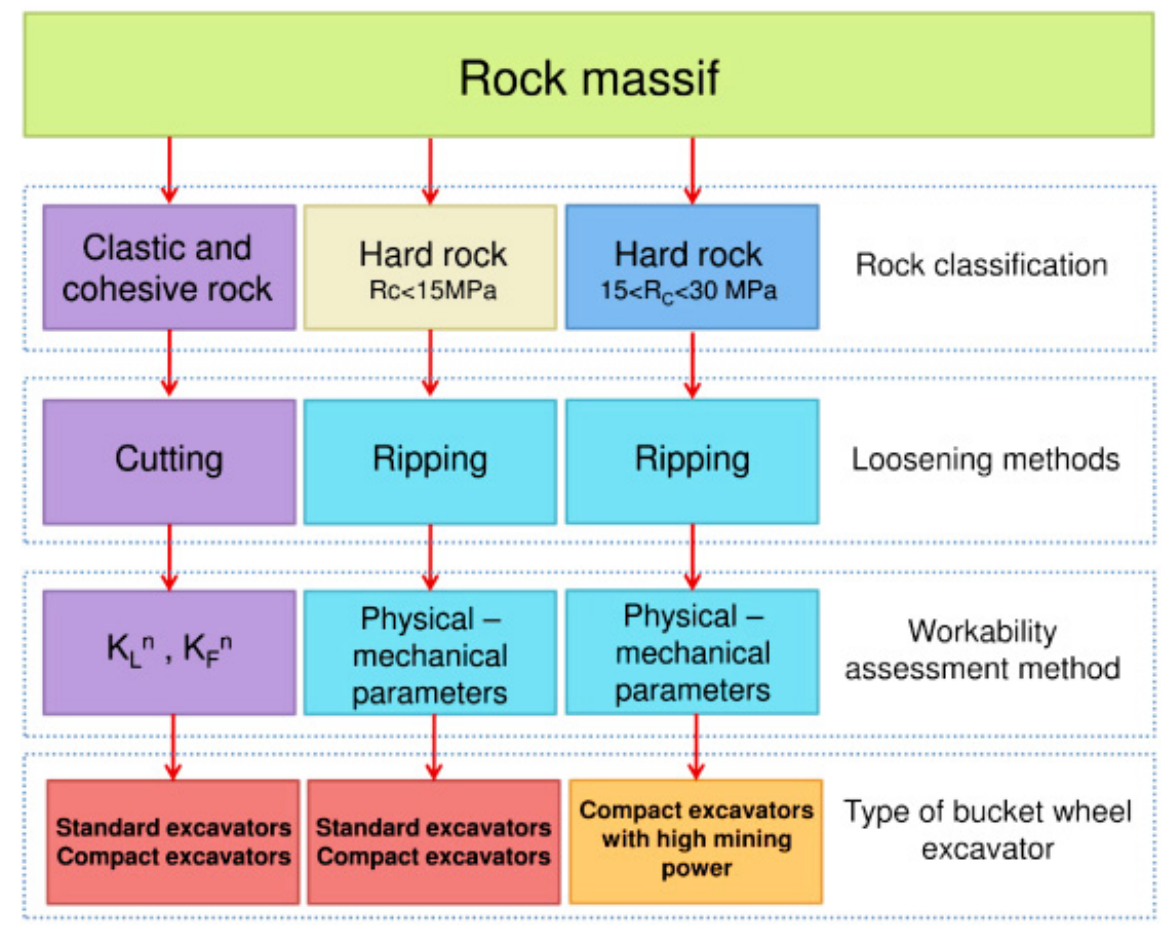

Fig. 1. Procedure acc. to new mining hypothesis with the selection of BWE, depending on the type of mined rock (Machniak, 2013)

According to Figure 1, in order to describe the workability process in hard rock, it is necessary to switch from unitary workability resistance to basic parameters characterizing both properties of rocks composing the rock massif and properties of the rock massif. These parameters mostly include: compression strength, tensile strength, crack distance, density, seismic wave speed, etc. This method of assessment of workability is used for other machines and devices such as: rippers (Weaver, 1975; For the tropical rock engineering Fields, 1998), cutting roadheaders (Dey et al., 2008), single-bucket excavators (Scoble et al., 1984), diamond circular saws for mining side coal beds (Mikaeil et al., 2011) as well as drills (Uysal, 2011). 
In case of bucket wheel excavators, the basic problem related to implementation of the workability determination method, based on physical and mechanical properties, is lack of experience in mining hard rock due to minimization of works under such conditions. This results from limiting the risk of damaging an excavator to minimum, which could be related to exceeding admissible design loads of such excavator and overloading the bucket wheel. The most accurate method of workability assessment is performing direct exploitation tests, however due to the aforementioned reasons, they are performed sporadically, and under some conditions, they are impossible to implement (exploitation designing stage). In such cases, the main parameter used to assess workability of hard rock is compressive strength. By analogy concerning the applied classification of workability for machines and devices, one can find that single-parameter assessment is too imprecise (Drebenstad, 2010; Machniak, 2013). To accurately determine the scope of BWE application, it is necessary to search for relationships (dependencies) with a few parameters at the same time.

The new hypothesis within the scope of workability of hard rock is justified with comparison of mining process using bucket wheel excavators with other machines of the same working character, e.g. rippers. There is the option of employing different mechanism to determine workability using rippers. Parameter consolidating operation of both these machines is mining energy $L S E$. Using the $L S E$ parameter in the assessment of rippers operation was published many times (Basair et al., 2004; Basair et al., 2007, 2008), however Bolukbasi et al. (1991), based on this parameter, proposed the parameter of workability using BWE. In the developed method of workability assessment, modified form of this classification was used, which is presented in Table 2.

TABLE 2

Modified workability classification based on LSE parameter

\begin{tabular}{|c|c|c|c|}
\hline \multirow{2}{*}{ Workability class } & \multicolumn{3}{|c|}{ Mining energy [MJ/m $\left.\mathbf{m}^{\mathbf{3}}\right]$} \\
\cline { 2 - 4 } & Minimum & Maximum & Medium \\
\hline Easily workable & 0 & 1.9 & 0.95 \\
\hline Workable & 1.9 & 3.7 & 3.8 \\
\hline Tough workable & 3.7 & 4.2 & 4.95 \\
\hline Not workable & 4.2 & - & \\
\hline
\end{tabular}

Classification acc. to Bolukbasi et al., (1991) specifies the option to mine rock massif from the point of view of technical implementation of the mining process, regardless of other limitations present in the mining process. Experience of many mines, including Brown Coal Mine "Bełchatów" unequivocally show that application of BWE in mining hard rock is limited by conditions related to design loads of the excavators, especially of the outrigger and bucket wheel. Considering the above information, modification is made by moving the limitation of BWE application to $L S E=4.2 \mathrm{MJ} / \mathrm{m}^{3}$, by extending the class "not workable" to cover the class "very tough workable" and eliminating it from the classification.

From the papers (Basair et al., 2004, 2007, 2008) it results that parameters of mined rock massif are very well correlated with the value of mining energy (ripping) in single-parameter relationships. Due to much more complicated mechanism of workability dependencies on the parameters of rock massif, Machniak (2013) performed a dimensional analysis of characteristic parameters to describe the process of mechanical mining of hard rock. As a result, he obtained 
empirical dependence between mining energy $(L S E)$ and the compressive strength, speed of seismic wave and bulk density of exploited rock massif, which is as follows:

$$
L S E=k \cdot \sqrt{R_{C} \cdot \gamma} \cdot v
$$

where:

$$
\begin{aligned}
L S E & - \text { mining energy (ripping) } \mathrm{MJ} / \mathrm{m}^{3}, \\
R_{C} & - \text { compressive strength, } \mathrm{MPa} \\
\gamma & - \text { bulk density of rock massif, } \mathrm{Mg} / \mathrm{m}^{3} \\
v & - \text { speed of seismic wave in the rock massif, } \mathrm{m} / \mathrm{s} \\
k & - \text { dimensionless coefficient, } k=0.00044 .
\end{aligned}
$$

Graphic representation of the derived dependence together with the assessment of workability for approximated compressive strength parameters, bulk density and adopted range of seismic wave speed in Jurassic rock in Brown Coal Mine "Bełchatów" is presented in Figure 2. This massif, according to RQD classes should be classified as medium good (Characteristics..., 2004). Considering the seismic wave speed in not cracked rock massif of $2400 \mathrm{~m} / \mathrm{s}$, the range of speed for medium good massif is from $1200 \mathrm{~m} / \mathrm{s}$ to $1800 \mathrm{~m} / \mathrm{s}$ (Dec, 2009).

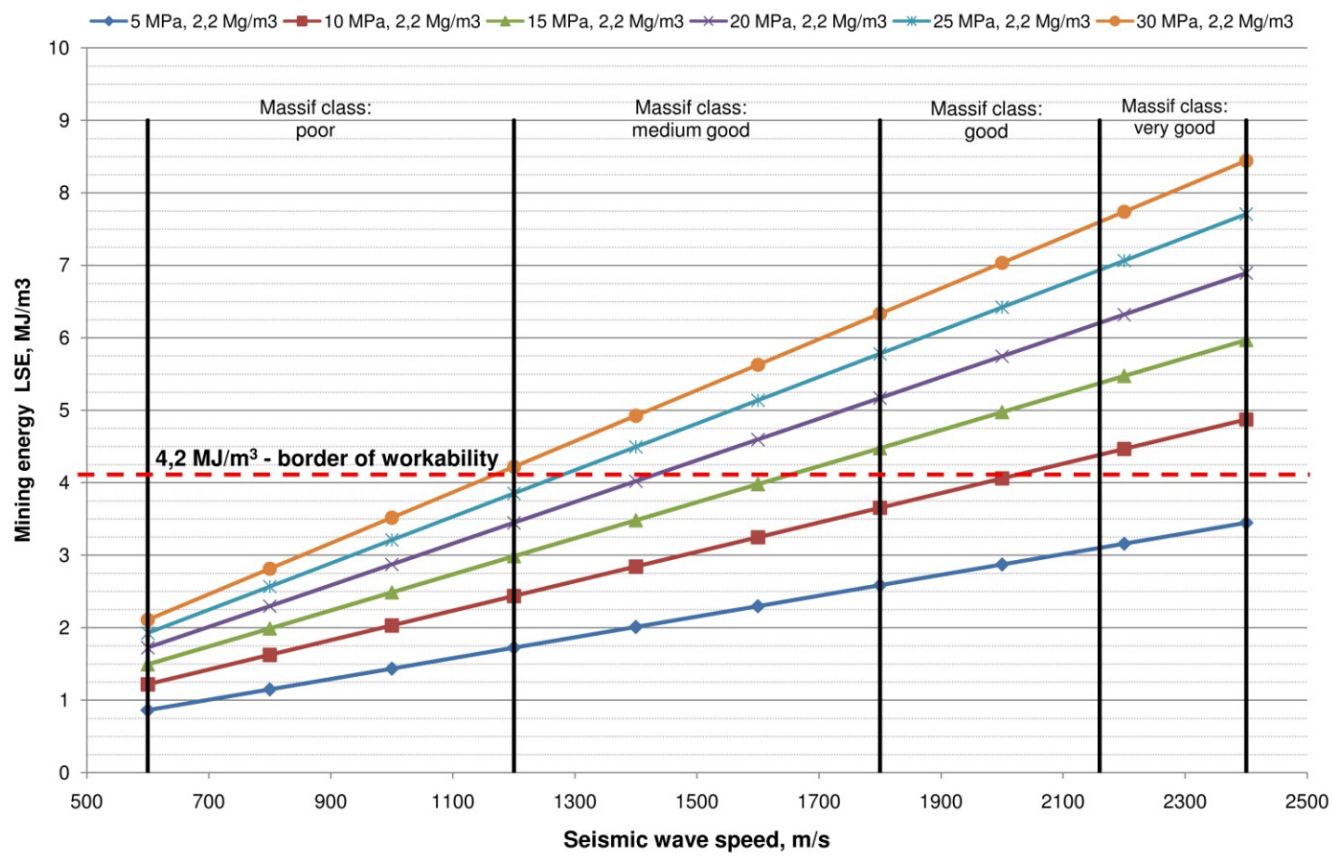

Fig. 2. Depiction of empirical dependence of mining energy to seismic wave speed in limestone in Brown Coal Mine "Bełchatów"

According to modified mining classification, mining with BWE is possible in medium good rock massif, characterized by compressive strength 15 to $30 \mathrm{MPa}$. However, for different values 
of compressive strength, the range of workability is possible only in limited range of seismic wave speed. Thus:

- $30 \mathrm{MPa}$ speed value to $1200 \mathrm{~m} / \mathrm{s}$ (within very limited range - at the brink of poor and medium good massif),

- $25 \mathrm{MPa}-1300 \mathrm{~m} / \mathrm{s}$,

- $20 \mathrm{MPa}-1500 \mathrm{~m} / \mathrm{s}$,

- $15 \mathrm{MPa}-1700 \mathrm{~m} / \mathrm{s}$.

This is confirmed by exploitation experience of Brown Coal Mine "Bełchatów", where the rock massif classified as medium good, of compressive strength 15 to $20 \mathrm{MPa}$, was found mechanically workable. However, the final range of workability is determined by direct exploitation tests, which are related to high risk of damaging the excavator. In turn, in case of value above $20 \mathrm{MPa}$, the rock massif is found as not workable. However, the peripheral areas of rock, which are cracked, can be mechanically mined with bucket wheel excavators.

According to prior art, mining rock is possible for compressive strength above $15 \mathrm{MPa}$. Based on Figure 2, this can partially be confirmed. Mining is possible only in case of medium good massif (for $15 \mathrm{MPa}$ below $1700 \mathrm{~m} / \mathrm{s}$ ) and for lower classes of its quality. In case of higher class of rock massif, workability is limited with seismic wave speed. In case of rocks of compressive strength $10 \mathrm{MPa}$, mining is admissible for speed below $2100 \mathrm{~m} / \mathrm{s}$. Seismic wave speed does not however limit workability of rock of compressive strength ca. 7.5 MPa and less.

\section{Summary}

Necessity of mining medium hard and hard rock in brown coal open pits, where the mining process is performed using bucket wheel excavators, is one of the major problems. With ambiguous share of this rock (below 10\%) in the exploited volume of the overburden, many exploiting difficulties occur (Machniak, 2013).

Presentation of new hypothesis concerning hard rock mining using BWE, that assume the mechanism of destroying rock structure by ripping, allowed for developing new method of workability assessment. This method details current classifications of workability.

The performed dimensional analysis of parameters characteristic for the description of mechanical mining of hard rock during the ripping process, resulted in empirical dependence between mining energy ( $L S E$ ) and compressive strength, seismic wave speed and bulk density of exploited rock massif. Combination of this dependence with modified workability classification with bucket wheel excavators (tab. 2) allows for multi-parameter assessment of workability class based on the independent variable parameters.

Especially important is the use of seismic wave speed, which considers difficult to measure properties of rock composing the rock massif and properties of rock massif. Seismic wave speed decreases together with the increase of the number of cracks in the rock massif, and this, according to the formula (1), causes the reduction of workability energy, which may lead to qualifying a given rock massif to more workable group despite the high compressive strength of rock forming the massif.

The developed new method of hard rock workability assessment is more versatile, because it allows for assessing the workability using seismic wave speed, eliminating at the same time the necessity to perform direct mining tests, which fact reduces the risk of damaging BWE. 
The presented classification of workability must be limited to standard design excavators. In case of compact excavators, their application can be extended, due to better design adaptation for operation under tough mining conditions. Range of application can be determined based on gathering more experience in exploitation of hard rock.

Paper prepared within the scope of statute studies No 11.11.100.597.

\section{References}

Abdullatif O.M., Cruden D.M., 1983. The relationship between rock mass quality and ease of excavation. Bulletin of the International Association of Engineering Geology, No. 28.

Babiarz S., Dudek D., 2007. Kronika awarii i katastrof maszyn podstawowych w polskim górnictwie odkrywkowym. Oficyna Wydawnicza Politechniki Wrocławskiej, Wrocław.

Basair H., Karpuz C., Tutluoglu L., 2007. A fuzzy logic based rippability classification system. The Journal of The Southern African Institute of Mining and Metallurgy, Vol. 107.

Basarir H.; Karpuz C., 2004. A rippability classification system for marls in lignite mines. Engineering Geology, No 74.

Basarir H.; Karpuz C., Tutluoglu L., 2008. Specific energy based rippability classification system for coal measure rock. Journal of Terramechanics, No. 45.

Bieniawski Z.T., 1975. The point load test in geotechnical practice. Engineering Geology, September.

Bolukbasi N., Koncagul O., Pasamehmetoglu A.G., 1991. Material diggability studies for the assessment of bucket wheel excavator performance. Mining Science and Technology, Vol. 13.

Davies A.L., McManus D.A., 1991. Geotechnical applications of downhole sonic logging for surface coal mining. Exploration Geophysics, No. 21.

Dec J., 2009; Sejsmiczna ocena spękania górotworu karbońskiego w rejonach płytkiej działalności górniczej. Geologia, Tom 35, Zeszyt 2/1.

Dey K., Ghose A.K., 2008. Predicting “Cuttability” with Surface Miners - A Rockamass Classification Approach. Journal of Mines, Metals and Fuels, V. 56.

Drebenstedt C., 2010. Use of environmental balance for selection of continuous or cyclic mining equipment on example of hard rock mining. Continuous Surface Mining, Freiberg (materiały konferencyjne).

Dział Geologiczny KWB Bełchatów, 2004. Charakterystyka skat mezozoicznych wystęujących w zboczach stałych wyrobiska górniczego KWB „Betchatów”. Rogowiec (praca niepublikowana).

Kavouridis K., Roumpos C., Galetakis M., Pavloudakis F., 2008. Methods and technological-improvements for the efficient removal of the overburden hard rock formations at South Field lignite mine, Ptolemais, Greece. Continuous Surface Mining, Romania (materiały konferencyjne).

Kołkiewicz W., 1973. Zastosowanie maszyn podstawowych w górnictwie odkrywkowym. Wydawnicto „Śląsk”.

Kołkiewicz W., 2006. Metody identyfikacji i optymalizacji podstawowego procesu technologicznego odkrywkowej eksploatacji złóż z zastosowaniem numerycznych technik symulacyjnych. Redakcja „Górnictwa Odkrywkowego”, Wrocław.

Kozioł W. Machniak Ł., 2010. Problemy klasyfikacji i wydobycia trudno urabialnych skat i gruntów w kopalniach węgla brunatnego. Górnictwo i Geoinżynieria, Rok 34, Zeszyt 4, Kraków.

Kozioł W., Barański K., Borcz A., Machniak Ł., 2013. Zastosowanie metod geofizycznych do identyfikacji skat trudno urabialnych w kopalniach węgla brunatnego. Górnictwo Odkrywkowe, R. $54 \mathrm{nr} 1$.

Kozioł W., Kaczarewski T., 1990. Problemy technologiczno-eksploatacyjne wydobycia skat trudno urabialnych w polskich kopalniach węgla brunatnego. Górnictwo Odkrywkowe, Nr 5-6.

Kramdibrata S., 1998. The Influence of Rockmass and Intact Rock Properties on the Design of Surface Mines with Particular Reference to The Excavatability of Rock. Ph. D. Thesis, School of Civil Engineering, Curtin University of Technology (praca niepublikowana). 
Machniak Ł., 2013. Metoda doboru technologii wydobycia utworów trudno urabialnych w kopalniach węgla brunatnego. Rozprawa doktorska, AGH, Kraków (praca niepublikowana).

Mikaeil R. i in., 2011. Development of a new classification system for assessing of carbonate rock sawability. Arch. Min. Sci. 56, 1.

Praca zbiorowa 1998. For the tropical rock engineering fields. Universiti Teknologi Malaysia (praca niepublikowana).

Praca zbiorowa, 1995. Identyfikacja i modelowanie warunków zalegania oraz wybierania trudno urabialnych kompleksów geologicznych zaburzonych złóż węgla brunatnego. Redakcja Górnictwa Odkrywkowego, Wrocław.

Schroeder D., Trumper R., 1993. Digging rock with bucket wheel excavators. Bulk Solid Handling, Vol. 13, No. 2.

Scoble M.J., Muftuoglu Y.V., 1984. Derivation of A Diggability Index for Surface Mine Equipment Selection. Mining Science and Technology, Vol. 1.

Strunk S., 2008. Optimising the production of problematic overburden in hambach opencast mine. 21 st World Mining Congress, Kraków (materiały konferencyjne).

Szepietowski W., 1991. Klasyfikacja urabialności skat nadkładowych wielonaczyniowymi koparkami kołowymi. Górnictwo Odkrywkowe, Nr 1, Wrocław.

Uysal O., 2011. The effect of mechanical properties of rock on the performance of down-the-hole drills. Arch. Min. Sci. 56,2 .

Weaver J. M., 1975. Geological Factors Significant in the Assessment of Rippability. Civil Engineering in South Africa, Vol. 17. 